\title{
MASJID TLA WAPAUWE: 598 TAHUN MERENTANG ZAMAN
}

\author{
The Wapauwe Old Mosque: 598 Years Stretching the Age \\ Oleh: Paisal* \\ * Peneliti pada Balai penelitian dan Pengembangan Agama Makassar \\ Kantor: Jl. A.P. Pettarani No. 72 Makassar \\ E-Mail: umar.faisalfajrocketmail.com
}

\begin{abstract}
Abstrak
Penelitian berupaya mengungkap struktur morfologi dari masjid Wapauwe di desa Keitetu yang merupakan salah satu saksi sejarah.Masjid ini telah ada jauh sebelum masuknya Belanda.Penelitian ini merupakan penelitian deskriptif eksploratif, yaitu penelitian kualitatifyang dilakukan dengan memberikan gambaran tentang data arkeologi mesjid kuno yang ditemukan serta memberikan penjelasan tentang fenomena tersebut. Data diperoleh dengan metode wawancara dan observasi langsung terhadap objek penelitian. Hasil penelitian menunjukkan bahwa Masjid Tua Wapaue bercorak tradisional menggunakan model piramida terpancung pada atapnya yang terbuat dari rumbia, konstruksi bangunan induknya dirancang tanpa memakai paku atau pasak kayu pada setiap sambungan, hanya diperkuat dengan ikatan dari tali penunjang kekokohannya.
\end{abstract}

Kara Kunci: Arsitektur, Morfologi, Masjid Wapauwe

\begin{abstract}
The study seeks to unravel the structure morphology of the mosque of Wapauwe in the Keitetu village which is one of the historical witnesses of mosque has existed long before the Dutch colonization. This research is an exploratory descriptive study, the qualitative research conducted with archaeological data provide a picture of an ancient mosque that was found and provide an explanation of the phenomenon. Data obtained by the method of interview and direct observation of the object of research. The results showed that the Old Mosque Wapaue is traditional patterned using the pyramid model beheaded on a roof made of thatch, its main building construction is designed without using nails or wooden pegs on each connection, only strengthened the bond of the rope supporting its robustness.
\end{abstract}

Keywords: Architecture, Morphology, Wapauwe Mosque

\section{PENDAHULUAN}

I slam sebagai sebuah agama yang membawa tatanan sosial baru hadir di wilayah Kepulauan Maluku setidaknya sejak akhir Abad XIV, yang ditandai dengan berdiri dan berkembangnya Kerajaan dengan pemerintahan bercorak Islam. Di Wilayah Maluku Utara dikenal empat Kerajaan Islam besar dan pengaruhnya tersebar luas yakni Ternate, Tidore, Bacan dan Jailolo. Di Wilayah Maluku bagian selatan, dikenal juga kerajaan yang cukup besar pengaruhnya dan perkembangannya sejaman dengan wilayah kerajaan Ternate, yakni Kerajaan Hitu, di bagian utara Pulau Ambon. Perkembangan kerajaan-kerajaan tersebut seiring pula dengan laju gerak niaga yang melibatkan para pedagang asing seperti pedagang Arab, Persia, China, Jawa serta Sumatera. Berkembangnya gerak niaga, dipicu oleh kekayaan sumberdaya alam yang dimiliki oleh wilayah kepulauan Maluku, yakni cengkeh dan pala yang terkenal seantero jagad.
Interaksi wilayah Maluku dengan budaya Islam dapat ditelusuri dengan adanya bukti-bukti peninggalan budaya Islam pada awal persentuhannya hingga masa berkembangnya sebagai agama resmi kerajaan. Di Wilayah Ternate, Tidore, Bacan dan Jailolo, bukti-bukti peninggalan kerajaan Islam seperti Majid Kuno, Alquran kuno dan berbagai peninggalan lainnya membuktikan bahwa pengaruh budaya Islam di wilayah itu sangat kuat. Dapat dikatakan wilayah Ternate, Tidore, Jailolo dan Bacan adalah wilayah-wilayah pusat peradaban Islam. Pada abad XV-XVI Ternate, Tidore, Bacan, Jailolo di Maluku Utara adalah wilayah-wilayah pusat Kerajaan Islam yang pengaruhnya menyebar ke seluruh wilayah Kepulauan Maluku, bahkan hingga ke sebelah barat dan timurnya. Di bagian selatan Maluku, Kerajaan Hitu di Pulau Ambon dianggap sebagai pusat kekuasaan Islam. Dari wilayah pusat' peradaban dan kekuasaan Islam inilah, kemudian dengan cepat berkembang ke wilayah-wilayah lainnya, seiring laju perdagangan serta ekspansi kekuasaan. 
Budaya Islam pada masa awal perkembangannya di Indonesia setidaknya dapat meninggalkan warisan berupa; 1). bangunan/monument/fitur: mesjid, menara, pesantren, madrasah, rangkang, gapura, istana, makam, taman kerajaan, benteng, ghunongan,balai karapatan, rumah tinggal kaum bangsawan dan lain-lain; 2). artefak bergerak: perlengkapanmasjid; mimbar, maksurah, cis dan sebagainya.

Masjid merupakan bangunan yang paling khas sebagai simbol keagamaan, dan sebagai produk budaya masyarakat yang heterogen. Masjid di Indonesia tampak berbeda dengan masjid yang berada di wilayah Timur-Tengah, atap masjid kuno di Indonesia tidaklah mengambil bentuk kubah, tapi mengambil bentuk atap tumpang, bahkan ada yang bertingkat seperti dua tingkat yang terlihat pada Masjid Agung Cirebon, lima tingkat seperti pada Masjid Agung Banten, hingga tujuh tingkat pada Masjid Agung lama Ternate. Mengenai bentuk tumpang pada atap masjid-masjid kuno di nusantara, Pijper berpandangan bahwa bentuk tumpang tersebut mungkin berasal dari bentuk mem pada masa Hindu-Jawa. ${ }^{2}$

Idealnya masjid-masjid kuno itu dilestarikan dan dijaga keasliannya. Akan tetapi faktanya di Indonesia masjid-masjid itu banyak dibongkar dengan alasan untuk perluasan atau karena kondisi bangunan yang sudah hancur. Pembongkaran mesjid biasanya dilakukan dengan mengahancurkan seluruh bangunan yang lama dan menggantinya dengan bangunan yang baru. Namun adajuga pembongkaran yang dilakukan sebagai upaya renovasi atau penggantian bahan-bahan yang rusak, kemudian dibangun kembali sebagaimana bentuk aslinya. Masjid-masjid hasil renovasi inilah yang banyak bertahan hingga saat ini, yang dapat dijadikan sebagai saksi sejarah atau sebagai bukti arkeologis yang dapat diteliti secara ilmiah.

Penelitian ini dilakukan di Desa Keitetu, Kecamatan Leihitu, Maluku Tengah, Provinsi Maluku dengan menetapkanMasjid Tua Wapauwe sebagai fokus amatan untuk menjawab bagaimana morfologi struktur dari bangunan Masjid Wapauwe?

Penelitian ini merupakan penelitian deskriptif eksploratif, yaitu penelitian kualitatif yang dilakukan dengan memberikan gambaran tentang data arkeologi mesjid kuno yang ditemukan serta memberikan penjelasan tentang fenomena tersebut, Mesjid sebagai objek kajian diarahkan dalam aspek kajian terhadap bangunannya sebagai wujud fisik (kajian arsitektur), karena mesjid adalah sebuah karya arsitektur. Pengumpulan data yang dilakukan dengan a), wawancara kepada tokoh masyarakat dan pemangku adat setempat. b). Observasi terhadap kehidupan sosial keberagamaan penduduk setempat. c). Data kepustakaan yang dikumpulkan dengan menelaah sumber-sumber tertulis seperti publikasi arkeologis (mesjid kuno) maupun sumber-sumber sejarah terkait.

\section{PEMBAHASAN}

\section{Tata Letak Masjid Tua Wapauwe}

Masjid Wapauwe berdiri di atas sebidang tanah bernama Teon Samaiha dalam bentuk yang sangat sederhana. Berada di antara pemukiman penduduk Negeri Kaitetu, Wilayah Kecamatan Leihitu, Kabupaten Maluku Tengah Propinsi Maluku. Keitetu merupakan dataran rendah dengan ketinggian 3 meter di atas permukaan laut.

Masjid Tua Wapauwe berada di daerah yang mengandung banyak peninggalan purbakala. Kurang lebih 50 meter ke arah Tenggara tepatnya di belakang perumahan penduduk dan pemakamanumum, berdiri sebuah rumah kecil berdinding gaba-gaba (pelepah sagu yang kering) berukuran 4 x 4 meter. Masyarakat Kaitetu menyebutnya luma ana sedangkan umumnya masyarakat Maluku Tengah menyebutnya kakehang.

Sekitar 150 meter dari masjid ke Utara, di tepi jalan raya terdapat sebuah gereja tua peninggalan Portugis danBelanda. Gereja ini dibangun pada kurun waktu 1680-1681 oleh pengawas perdagangan setempat bernama Jacob William Beth ketika Maluku di bawah pimpinan Gubernur Bernardus Van Pleuren. Gereja dibangun tidak jauh dari Benteng New Amsterdam berfungsi sebagai tempat beribadahtentara Belanda serta penduduk sekitar yang beragam Kristen. Gereja tersebut bernama Imanuel yang artinya "Tuhan beserta kita".' Gereja Immanuel yang ada saat ini bukan lagi merupakan bangunan asli. Hal ini disebabkan pada saat terjadi kerusuhan di Maluku pada tahun 1999, gereja tersebut dibakar hingga rata dengan tanah.

\footnotetext{
' Tawalinuddin Haris, Makalah Workshop Metode Penelitian Arkeologi Keagamaan, Bidang Lektur.dan Khazanah Keagamaan Balai Litbang Agama Makassar, tanggal 21-24 Maret 2011 di Hotel Mercure Makassar

Pijper, G.F., "Mesjid-Mesjid di Pulau Jawa", dalam: Tudjimah (Penerjemah). 1984. Penelitian Tentang Agama Islam di Indonesia 19301950, Jakarta: Penerbit UI Press, h.14.

"Pattikayhatu.JA. 1987. "Inventarisasi dan Dokumentasi Peninggalan Sejarah dan Purbakala di Kecamatan Leihitu Pulau Ambon", h. 19.
} 
Limapuluh meter dari gereja ke Utara berdiri dengan kokoh sebuah benteng tua, bernama "New Amsterdam" peninggalan bangsa Belanda. Letaknya di tanjung yang bernama Tetuyoga dan merupakan tempat yang strategis bagi Belanda dalam melawan rakyat TanahHitu melalui Perang Wawane (16341643) serta Perang Kapahaha (1643 - 1646).

Menurut catatan sejarah dari Rumphius, Benteng Amsterdam pada mulanya adalah sebuah loji yang terbuat dari kayu. Kemudian karena ancaman peperangan dengan rakyat Hitu di bawah pimpinan Kakiali, maka sekitar tahun 1637 Gubernur Jan Otsens serta penggantinya Demmer membangun menjadi sebuh benteng batu kecil.

\section{Islamisasi Dibalik Sejarah Berdirinya Mesjid Wapauwe}

Berdirinya Masjid Wapauwe di Negeri Kaitetu tidak terlepas dari sejarah perjalanan para mubaligh Islam yang datang dari Timur Tengah dengan membawa ajaran Islam ke dalam tatanan kehidupan masyarakat yang mendiami bagian utara Pulau ambon, yakni jazirah Hitu yang lebih dikenal dengan sebutan "Tanah Hitu". Cerita kedatangan penyiar Islam dapat ditemukan dalam cerita rakyat dan sebuah naskah "Hikayat Tanah Hitu" yang ditulis oleh Safar Ar Rijali salah seorang pejuang Islam Tanah Hitu yang lebih dikenal dengan sebutan Imam Rijali.

Menurut Imam Rijali, kehadiran penyiar Islam ketika itu bukan melalui perantaraan para pedagang dari Gujarat, tetapi justru orang-orang Persia yang datang dengan misi khusus untuk menyiarkan dan memasyarakatkan syariat Islam. Ini dilandasi oleh pengaruh percaturan politik yang terjadi pada era dinasti Mu'awiyah di Timur Tengah (Abad VII-VIII M), umat Islam berinisiatif membuka ekspansi dakwahnya baik karena telah mendengar kerajaan- kerajaan Hindu Buddha di Asia Tenggara maupun dinasti Tang di Negeri Cina.

Selanjutnya terjalin kontak perdagangan antara orang Timur Tengah dengan masyarakat Maluku yang membuat jaringan perdagangan orang-orang Arab di Asia Tenggara makin kuat. Di samping itu, mereka masuk lewat pendekatan kelembagaan. Corak Islam diperkenalkan lewat satu lembaga di Tanah Hitu, yakni; "Upu Hata" dan lewat misi Kesultanan Moloku Kie Raha, disaat Maluku Selatan belum punya penguasa yang terorganisir secara kelembagaan.

Kedatangan cucu dari Kesultanan Jailolo yang bernama Jamilu sekitar $1400 \mathrm{M}^{6}$ semakin memperkuat pengaruh Islam di Hitu. Menurut JA. Pattikayhatu' bahwa sebelum kedatangan Perdana Jamilu pada pertengahan abad ke-15 penduduk di pegunungan Wawane itu telah memeluk agama Islam. Bersama dengan penyiar Islam sebelum era Jamilu yang bernama Tuni Maulana penduduk membangun masjid yang bentuknya sangat sederhana.

Menurut sumber-sumber lokal, Kepulauan Maluku pada umumnya telah dikunjungi umat Islam setidaknya sejak abad ke-14 ketika Ternate dipimpin oleh Raja Molomateya (1350-1357). Muslim Arab yang datang ke Ternate telah memberikan petunjuk pembuatan kapal. Setelah kepemimpinan Marhum, kemudian datang maulana Husein dari Jawa yang ahli dalam menulis teks Arab dan membaca Al-Qur'an, sehingga menarik perhatian dari rakyat Maluku. Namun demikian, Raja yang Ternate yang terkenal memeluk Islam adalah Zainal Abidin yang dipanggil dengan sebutan Bulawa (raja rempa'h-rempah) yang memimpin dari tahun 1468-1500 dan mengunjungi Sunan Giri di Gresik dengan di temani Pendeta (Perdana) Jamilu. ${ }^{8}$

\footnotetext{
"Ibid., h. 21

"Upn hala merupakan Sistem pemerintahan 4 perdana digagas bermula ketika kedatangan empat orang pemimpin ke tanah Hitu. Empat perdana tersebut saling melengkapi dalam membentuk satu pemerintahan yang berdaulat. 4 perdana tersebut yakni Pendatang Pertama adalah Pattisilang Binaur dari Gunung Binaya (Seram Barat). Pendatang Kedua adalah Kyai Daud dan Kyai Turi disebut juga Pattikawa dan Pattituri dengan saudara Peretnpuannya yang bernama Nyai Mas. Kemudian datang lagi Jamilu dari Kerajaan Jailolo. Sebagai Pendatang terakhir adalah Kie Patti dari Gorom (P. Seram bagian Timur) yang diperkirakan tiba di Tanah Hitu pada tahun 1468, keempat pendatang tersebut kemudian bergelar Perdana Kemudian Empat Perdana itu mendirikan negeri yang letaknya kira-kira satu kilo meter dari Negeri Hitu (sekarang menjadi dusun Ama Hitu/Aman Hitu) disitulah awal berdirinya Negeri Hitu yang menjadi Pusat kegiatan kerajaan Tanah Hitu, bekasnya yang masih dapat ditemukan sampai sekarang adalah Pondasi Mesjid. Mesjid tersebut adalah mesjid kedua setelah masjid Wapauwe, mesjid itu bernama Masjid Pangkat Tujuh karena struktur pondasinya tujuh lapis. Ke-4 perdana itu kemudian sepakat mengangkat anak dari Pattituri adik kandung Perdana Pattikawa atau Perdana Tanah Hitu yang bernama Zainal Abidin dengan Pangkatnya Abubakar Na Sidiq sebagai Raja Kerajaan Tanah Hitu yang pertama yang bergelar Upu Lata Sitania pada tahun 1470. (Disarikan dari berbagai sumber).

${ }^{\circ}$ Sumber yang berbeda berdasarkan catatan sejarah Kerajaan Ternate bahwa Perdana Jamilu meninggalkan Jailolo pada tahun 1465 M 'Pattikayhatu. 1987. Inventarisasi dan Dokumentasi Peninggalan Sejarah dan Purbakala di Kecamatan Leihitu Pulau Ambon. Hal; 25. ${ }^{8} \mathrm{Uka}$ Tjandrasasmita. op.cit. h. 60 .
} 
Sumber lain yang dikutip Tjandrasasmita adalah Suma Oriental yang ditulis oleh Tome Pires (1512-1515) dan A Treavise on The Molluccas-Historia das Moluccas yang ditulis Antonio Galvao sekitar tahun 1544, memberikan pendapat yang sama bahwa rajaraja di Maluku memeluk Islam sekitar 1460-1465. Menurut Tome Pires, Raja Ternate yang memeluk Islam adalah Sultan Ben Acorala dan hanya raja Ternate ini yang menggunakan gelar Sultan, sementara raja-raja lain disebut dengan RajalRajo atau Kolano. Selain ternate dan Tidore, Tome Pires juga menyebutkan bahwa pada saat itu umat Islam telah ditemukan di Banda, Haruku, Makian, Motir dan Bacan.'

Kedatangan Perdana Jamilu di Pulau Ambon adalah untuk mengembangkan ajaran Islam kepada lima negeri di sekitar pegunungan Wawane, yakni, Essen, Wawane, Atetu, Nukuhaly dan Tehala. Jamilu sangat dicintai oleh masyarakat Wawane karena beliau sangat arif dan bijak dalam memberikan pengajaran agama Islam di dalam Masjid ini.Selanjutnya beliau bahu membahu dengan masyarakat memperbaiki dan melengkapi masjid. Sehingga di kemudian hari untuk menghargai jasajasanya, maka rakyat menamai masjid tersebut dengan Masjid Jamilu. Saat ini lebih dikenal dengan nama Masjid Wapauwe yang terletak di Negeri Keitetu.

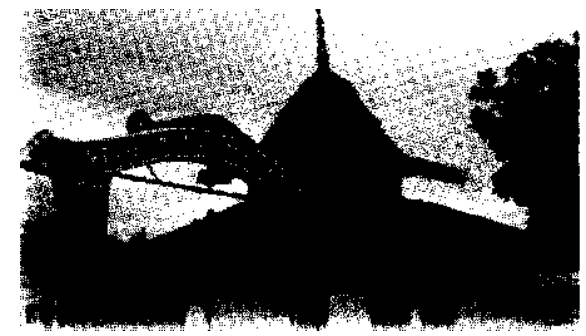

Masjid Tua Wapauwe Kaitetu

Tentang Masjid Wapauwe dikisahkan bahwa sebelum timbulnya Perang Wawane yang dimulai tahun 1634, kedatangan Belanda mengganggu kedamaian penduduk Tanah Hitu. Karena tidak merasa aman, maka pada tahun 1614 masjid tersebut dipindahkan ke kampong Tehala yang berjarak $6 \mathrm{~km}$ sebelah Timur Wawane. Hal ini menggambarkan betapa tingginya sifat kegotongroyongan masyarakat Keitetu dengan bahu membahu memindahkan masjid dari perbukitan Wawane menuju Tehala. ${ }^{10}$

Pemindahan masjid menuju suatu dataran yang banyak tumbuh pepohonan mangga hutan atau mangga berabu (dalambahasaKaitetu disebut "Wapa" sementara dalam bahasa Hitu disebut dengan "Wapu"), di bawah pepohonan itulah kemudian masjid didirikan kembali. Itulah sebabnya maka masjid tersebut diganti namanya menjadi "MASJID WAPAUWE", artinya Masjid yang didirikan di bawah pepohonan mangga berabu (mangga hutan) sehingga masjid ini dinamakan masjid Wapauwe (ffc/*z=Mangga, Uwe=pohon).

Tahun 1646 akhirnya Belanda dapat menguasai seluruh Tanah Hitu. Dalam rangka kebijakan politisnya dilakukan proses penurunan penduduk yang masih banyak tersisa dari negeri-negeri di pegunungan ke tepi pantai. Hal ini berlaku tidak terkecuali penduduk 5 negeri Wawane. Proses pemindahan lima negeri itu terjadi pada tahun 1664 dan tahun itulah kemudian ditetapkan sebagai tahun berdirinya Negeri Kaitetu.

\section{Deskripsi Bangunan Mesjid Wapauwe}

Masjid Wapauwe sejak awal sampai pindah di tempat yang baru sekarang selalu didirikan di tengahtengah pemukiman penduduk Masjid ini sampai sekarang tetap digunakan baik untuk shalat Jum'at maupun shalat lima waktu walaupun sudah ada masjid Hena Telu yang lebih besar dibangun pada tahun 1912 Masehi.

Berdiri di atas tanah seluas 250 meter persegi, bangunan induk Masjid Wapauwe hanya berukuran 10 x $10 \mathrm{~m}$, sedangkan bangunan tambahan yang merupakan serambi, berukuran 6,35 x 4,75 m. Tipologi bangunan masjid dilihat dari bentuk denah termasuk tipologi segi empat bujur sangkar. Bangunan asli pada saat didirikan tidak mempunyai serambi. Atap masjid berbentuk piramida terpancung bertingkat dua.

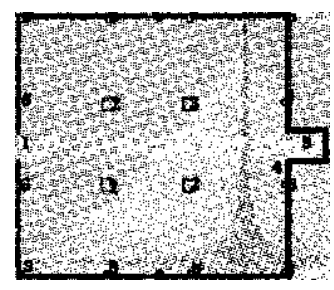

\section{Keterangan Gambar:}

1. Pintu Utama

2. Tiang utama 4 buah

'Ibid. Uka Tjandrasasmita Hal. 60.

Dja'far Lain, Wawancara Ambon 27 Mei 2011. Pukul 13.40. 
3. Mihrab

4. Mimbar

5. Tiang penopang 12 batang

6. Jendela di sebelah utara dan selatan

Serambi/bangunan tambahan

Gerbang utama disebelah barat

Sumur

10. Prasasti oleh Ketua LIPI Bachtiar Rifai pada tahun 1982

Perpaduan gaya arsitektur lokal dan Jawa menghiasi dan menjadi salah satu keistimewaan masjid ini. Hal ini terletak pada konstruksi bangunan induknya yang dirancang tanpa memakai paku atau pasak kayu pada setiap sambungan, baik antara tiang dengan balok maupun antara balok dengan balok. Tiang-tiang dan balok dikaitkan satu sama lain dengan teknik penempelan khusus kemudian diikat dengan tali ijuk (gemutu). Menurut Joseph dan Frans Rijoli bahwa secara umum ciri khas bangunan tradisional di Maluku terletak pada struktur konstruksi bangunan bersifat tradisional sesuai dengan kemajuan teknologi pada zamannya dengan memanfaatkan unsur material lokal. Selain itu umumnya detail bangunan diselesaikan dengan sistem lidah, pasak dan ikatan yang dapat menjamin kokohnya bangunan."

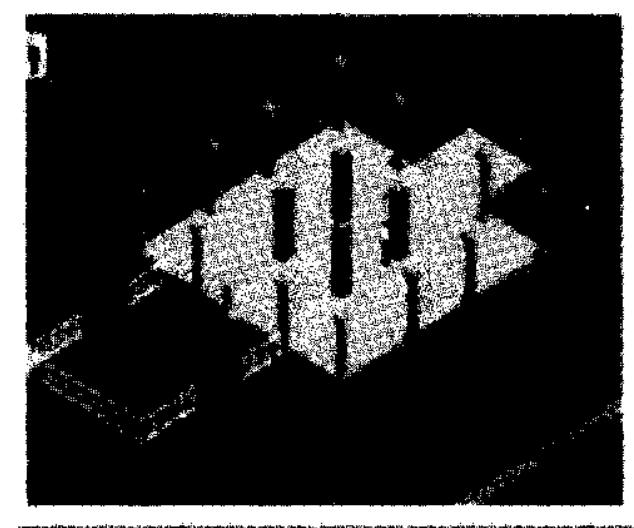

Gambar: Peletakan tiang masjid

Atap terbuat dari bahan daun sagu (rumbia), pergantian atap dilakukan apabila telah terjadi kerusakan dan diperkirakan sekitar 10 tahun dengan disertai upacara adat. Inisiatif renovasi datangnya dari Raja yang memerintahkan kepada Lehulat (penghubung) untuk memberitahukan kepada Ayoul (arsitek) dan Tukang Ela (tukang besar) untuk melakukan perbaikan.
Proses pergantian atap dilakukan dengan bergotong royong. Setiap penduduk yang terdiri dari satu kepala keluarga masing-masing menyumbangkan satu ikat daun rumbia yang terdiri dari 25 bangkawang. ${ }^{12}$

Di bagian ujung tritis dengan ikatan pertama yang terletak pada ujung atap terdapat ukiran pasak berbentuk buah nanas, selain sebagai hiasan juga merupakan pengancing lisplank. Pada keempat sudut tritis baik pada atap tingkat bawah maupun atap tingkat atas, di bawah tritisnya terdapat kayu yang berukir dengan motif kaligrafi bertuliskan "Allah-Muhammad" (sudut Timur-Barat) dan "Muhammad" (sudut UtaraSelatan).

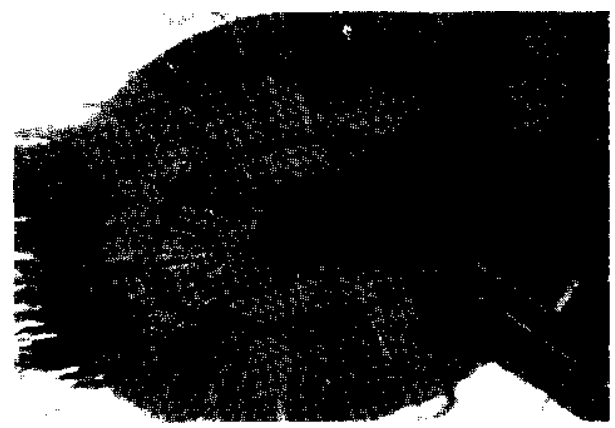

Gambar: Ujung tritis sudut timur-barat

Pada bagian sudut kiri atas daun pintu tua yang asli terdapat lempengan kuningan berbentuk seekor kura-kura. Di bagian tubuh kura-kura tersebut terdapat tulisan Shalawat Nabi yang bermakna pengagungan dan do'a keselamatan sedangkan kura-kura digambarkan sebagai tempat berdirinya masjid yang tidak jauh dari bibir pantai tempat ditemukannya binatang tersebut.

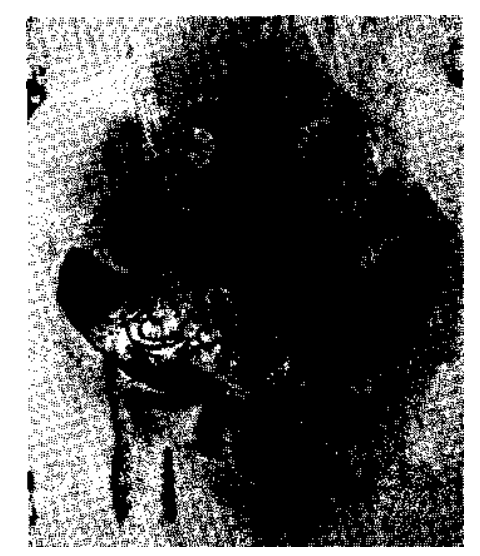

Gambar: Lempengan berbentuk Kura-kura

Joseph, LC. Dan Rijoli, Frans. 2005. "Arsitektur Tradisional Maluku". Dalam Maluku Menyambut Masa Depan Ambon. Lembaga Kebudayaan Daerah Maluku. Hal: 50.

${ }^{2}$ Dja'far Lain. Wawancara Ambon 27 Mei 2011. Pukul 13.40. 
Di sebelah selatan dari bangunan serambi terdapat sebuah sumur yang berfungsi sebagai tempat berwudhu. Dalam kompleks masjid juga terdapat tempat penyembelihan qurban yang terletak pada sudut luar bagian barat halaman masjid menyerupai kuburan. Selain itu terdapat di sudut selatan dari tempat tersebut atau di bagian luar pagar juga terdapat kuburan Abd. Hamid Lumaela beserta kedua buyutnya. Orang kaya Abd. Hamid Lumaela meninggal dunia pada tahun 1918

\section{Morfologi Masjid}

\section{Bagian Kaki}

Pada bagian alas bangunan terdapat pondasi yang terbenam ke dalam tanah sedalam kurang lebih $40 \mathrm{~cm}$ dan tinggi dari permukaan tanah $50 \mathrm{~cm}$ dengan panjang 9,70 meter dan lebar 9,65 meter. Pondasi bagian serambi lebih rendah letaknya dari pondasi ruang utama. Tiang soko guru berdiri di atas alas (umpak) berukuran 50 x $50 \mathrm{~cm}$ dengan tinggi $40 \mathrm{~cm}$, diperkirakan alas tiang tersebut dibuat ketika dilakukan renovasi, bentuknya segi empat dan terletak di atas lantai ruang utama.

\section{Bagian tubuh bangunan}

Dinding Utara, Selatan, Timur dan Barat, masingmasing berukuran 9 meter persegi. Terbuat dari tembok pada bagian bawah sedangkan bagian atas dibuat dari susunan gaba-gaba yang diatur secara vertikal, diapitolehtiang-tiang dinding berjumlah empat buah setiap belahan dinding. Pada bagian dinding sebelah Timur terletak pintu utama. Merupakan satusatunya pintu dari masjid ini yang menghadap ke ruangan serambi berukuran lebar 1,07 meter dan tinggi 1,83 meter.

Dinding bagian serambi terbuat dari tembok setinggi $1 \mathrm{~m}$, sedangkan bagian atasnyaterbuka. Kalau diperhatikan lebih teliti, maka keempat bagian dinding tersebut terdiri atas dua lapisan. Baik usuk maupun lisplank diperkuat dengan tali ijuk dengan bentuk ikatan yang artistik.

Pada bagian dinding sebelah utara dan selatan terdapat masing-masing 1 buahjendela berukuran lebar $100 \mathrm{~cm}$ dan tinggi $113 \mathrm{~cm}$ terbuat dari kayu nani (Bintanggur atau Callophylum Soulattri) dengan masing-masing 2 buah daun jendela. Pada setiap belahan dinding bagian atas ruang utama terdapat

\footnotetext{
${ }^{13}$ Dja'far Lain, Wawancara. Ambon 27 Mei 2011. Pukul 13.40

" Lihat catatan kaki nomor 5.
}

ventilasi yang berguna sebagai tempat keluar masuknya udara. Pada bagian dinding di sebelah Barat, terdapat bangunan yang menjorok keluar dengan ukuran 1,50 x 1,25 m selain berfungsi sebagai mihrab juga merupakan penanda arah kiblat.

\section{Bagian Atap}

Langit-langit di dalam masjid berbentuk terbuka tidak diberi plavond, hanya terdiri dari susunan konstruksi penopang atap yang bertumpu pada 4 tiang utama soko guru dan ditopang oleh tiang pembantu yang mengelilingi sebanyak 12 buah yang juga berfungsi memikul rangka atap sebelah bawah. Konstruksi atap terbuat dari Kayu Merah berbentuk piramida.

Baik susunan rangka atap bagian bawah maupun susunan rangka atap menara atas secara konstruktif semuanya berpusat pada keempat tiang induk (soko guru) yang terbuat dari bahan kayu nani I Bintanggur atau Callophylum Soulattri, berdiameter 30 x $30 \mathrm{~cm}$. Tiang utama yang berjumlah 4 buah melambangkan 4 sahabat utama Nabi Muhammad SAW. ${ }^{13}$ Ada pula yang menganggap bahwa tiang utama tersebut bermakna sistem pemerintahan Upu Hata ${ }^{14}$ yang pernah dipakai pada zaman awal pendirian kesultanan Hitu. Namun penulis lebih sepakat dengan pendapat pertama karena kedatangan empat perdana yang merupakan cikal bakal kerajaan Hitu jauh setelah masjid ini berdiri.

Ketika menelusuri tradisi masyarakat Keitetu sendiri dan jazirah Leihitu pada umumnya sangat mengagungkan bulan kelahiran Rasulullah SAW. Ritual peringatan Maulid sangat meriah dan juga kita bisa mendapati tradisi pembacaan naskah Doa Waite. Doa Waite sendiri bermakna memutar untuk mencari bulan baik dimana pada salah satu hari di bulan itu akan lahir manusia yang dimuliakan Allah yakni Muhammad SAW.

Atap Masjid Wapauwe terdiri atas 2 tingkat yang runcing ke atas yang berbentuk limas. Ditutup dengan atap rumbia (sagu) dan pada setiap bubungan dilapisi ijuk (gemutu) sampai ke puncaknya dan ditutup dengan kubah (mustaka).

Gaya bangunan atap yang berbentuk limasan dipengaruhi oleh pendatang dari Jawa. Asal muasal penduduk Tanah Hitu berasal dari Jawa. Hal ini 
dikaitkan dengan perpindahan keturunan Raja Tuban. Mereka kemudian sampai di Tanah Hitu yang di belakang hari bersama dengan tiga pendatang lainnya mendirikan kerajaan Hitu. ${ }^{15}$

Kisah kedatangan orang Jawa dapat diketahui dari Hikayat Tanah Hitu yang ditulis oleh Iman Rijali pada Abad 16. Masih terkait dengan pengaruh Jawa pada bangunan masjid adalah adanya kisah perjalanan dari Peruana Jamilu yang sempat belajar ke Tanah Jawa. ${ }^{16}$

Pada bangunan menara atau bagian atap tingkat dua di atas bangunan induk terbuat dari dinding gabagaba berukuran: 3 meter x 3 meter $\mathrm{x}$ dan tinggi 1,5 meter. Model konstruksi rangka atap berbentuk piramid.

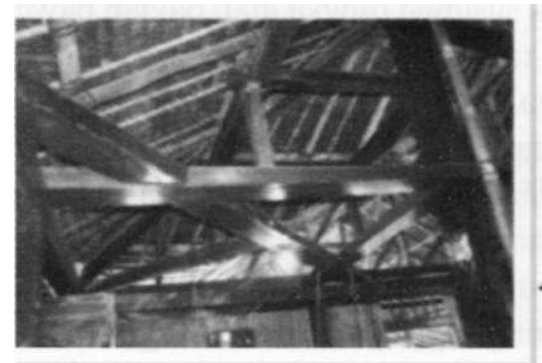

Gambar: konstruksi atap

Tiang pembantu di sekeliling bangunan berdiameter $25 \times 35 \mathrm{~cm}$ terbuat dari kayu merah. Keempat tiang utama menopang langsung pada 4 balok yang berfungsi sebagai tumpuan usuk atap tingkat dua. Di bawah balok atap tingkat dua terdapat balok bersusun terbuat dari kayu merah yang berfungsi sebagai tumpuan atap tingkat satu. Jarak antara balok tingkat dua dengan balok tingkat satu adalah satu meter. Bagian atap tingkat pertama atau bagian bawah ditopang oleh ke-12 tiang tersebut.

Tiang yang berjumlah 12 buah bermakna tanggal kelahiran Rasulullah SAW. Pendapat lain menyatakan bahwa tiang berj umlah 12 adalah perlambangan dari 5 rukun Islam dan 6 rukun iman ditambah 1 akhlakul karimah sebagai salah satu tugas utama kerasulan Muhammad SAW."

\section{Bagian Kemuncak}

Pada bagian puncak masjid terdapat tiang alif (mustaka) setinggi $2.5 \mathrm{~m}$ terbuat dari kayu Nani (Bintanggur atau Callophylum Soulattri), dilam- bangkan sebagai Arsy (Al Khalik) Allah Yang Maha Tunggal pelindung bangunan dan hamba-Nya.

\section{Gambar: Puncak Masjid Wapauwe}

Tiang alif yang terpasang di bagian kemuncak saat ini merupakan duplikat. Adapun tiang asli pertama yang dibuat padatahun $1700 \mathrm{M}$. Dari kayu Bintanggur atau Callophylum Soulattri diletakkan di bagian serambi masjid. Selain itu terdapat pula sejumlah tiang dan balok asli, serta atap puputasli yg telah diganti karena mengalami kerusakan.

\section{Susunan Ruang dan Fungsinya \\ a) Ruang Serambi}

Berukuran 6.35 x 4.75 meter, merupakan ruang terbuka dibatasi separuhdinding tembok. Letak lantai ruangan ini lebih rendah dari ruangan utama. Mempunyai fungsi sebagai ruang tunggu para jamaah atau kegiatan keagamaan lainnya. untuk masuk ke ruangan utama kita akan melewati pintu serambi yang terletak pada sisi utara ruang serambi. Sedangkan pintu sebelah selatan ruang serambi, gunanya untuk mengambil air wudhu dan ke kamar kecil.

\section{b) Ruang Utama}

Berukuran $9 \times 9$ meter. Ditengah ruang utama inilah terdapat 4 buah tiang utama (sokoguru) setinggi 7 meter yang merupakan pusat konstruksi bangunan bagian bawah maupun bagian atap. Pada bagian tengah di antara keempat tiang utama terdapat lubang berukuran $30 \times 30 \mathrm{~cm}$ yang ditutup rapat dengan sebuah batu alasan yang merupakan pusat dari masjid. Di atas batu inilah Modin (Muadzin) menyuarakan Adzan. Di sebelah barat ruang utama ini pula tepatnya di sebelah kanan mihrab terdapat sebuah mimbar yang berfungsi untuk berkhotbah para khatib dengan dua bendera merah putih pada kiri kanannya.

"Mu jizah. 2008. "Pertemuan Antar Bangsa dalam Hikayat Tanah Hitu". Dari Hitu ke Barus. Pusat Bahasa Departemen Pendidikan Nasional Jakarta, h. 14

${ }^{16}$ Ibid, h. 18.

Dja'far Lain, Wawancara Ambon 27 Mei 2011. Pukul 13.40. 


\section{c) Ruang Pengimaman (Mihrab)}

Berukuran $125 \mathrm{~cm}$ x150 cm. Ruang ini adalah tambahan ruangan yang menjorok keluar dari pertengahan dinding sebelah barat. Dinding mihrab dibuat lebih rendah dari ruang utama. Fungsi dari mihrab ini sebagai tempat Imam dan sebagai lambang Ka'bah yang mengarah ke Barat (Kiblat), Kota suci Makkah.

\section{d) Lantai Masjid}

Pada awalnya terdiri dari batu kerikil putih, namun sekarang telah diganti dengan semen kemudian dilapisi dengan karpet dan sajadah.

\section{e) Pintu dan Jendela}

Pintu utama yang terletak di sebelah timur masjid berukuran $107 \mathrm{~cm}$ x $180 \mathrm{~cm}$ merupakan satu-satunya pintu di masjid ini. Pintu yang digunakan saat ini merupakan duplikat karena pintu asli telah mengalami kerusakan. Jendela 2 buah terletak di sisi utara dan selatan masjid berukuran $100 \mathrm{~cm}$ x $113 \mathrm{~cm}$ dengan menggunakan masing-masing 2 daun pintu.

\section{Benda-Benda Kelengkapan Masjid}

Mimbar; seusia dengan masjid, terdapat di dalam ruang utama sisi bagian barat berdekatan dengan Mihrab. Terbuat dari kayu nani dan kayu Lara \{Metrosideros). Berukuran panjang $180 \mathrm{~cm}$, lebar 86 $\mathrm{cm}$ dan tinggi $220 \mathrm{~cm}$.

\section{Gambar: Mimbar}

Bedug; terbuat dari Кауи Linggua, Angsana atau Sonokembang (Pterocarpus indicus), panjangnya 2 meter dengan ukiran tipis di bagian bawahnya. Kulit bedug terbuat dari kulit rusa. Semula panjang bedug ini 3 meter, namun pada masa penjajahan Belanda dipotong hingga hanya berukuran 2 meter. Oleh Belanda diperintahkan untuk dipotong karena pada saat bedug dipukul, gaungnya menggetarkan dinding benteng New Amsterdam yang berjarak $\pm 200 \mathrm{~m}$ sebelah barat masjid.

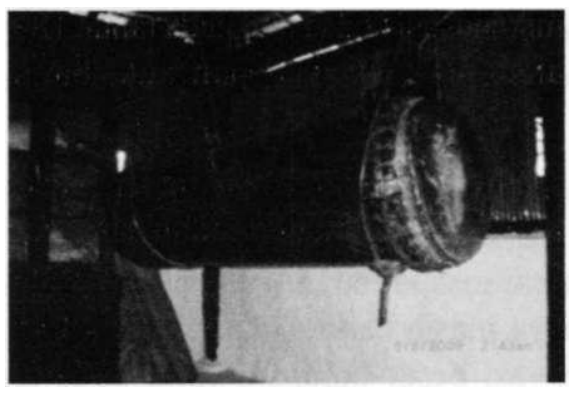

Gambar: Bedug tua yang kokoh

Tongkat Khotbah; terbuat dari sejenis kayu yang bagian luarnya beruas - ruas seperti rotan. Dibawa oleh Tuni Ulama, mubaligh dari Arab pada Abad XIIM.

Lampu Antik; bentuknya seperti piring yang pada pinggirannya ada lekukan-lekukan tempat meletakkan minyak kelapa sebagai bahan bakar dan tempat sumbu. Lampu antik ini ada 2 buah, besar dan kecil. Selain itu terdapat pula lampu antik peninggalan portugis yang dapat ditinggikan atau direndahkan dengan cara menarik atau menolak batu bebannya.

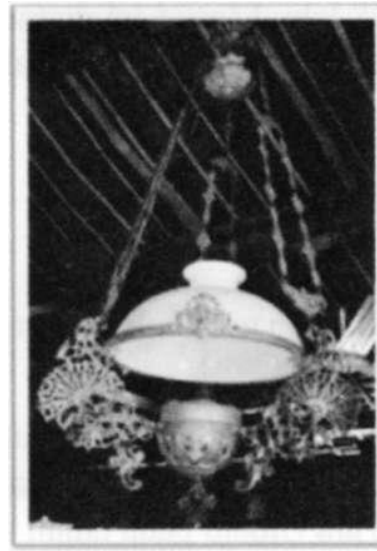

Gambar:Lampu Portugis

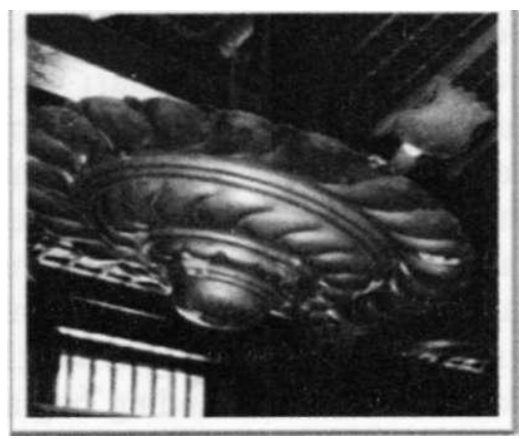

Gambar: Lampu Minyak Antik 


\section{Renovasi}

Masjid ini direnovasi pertama kali oleh Perdana Jamilu pada tahun 1464, tanpa mengubah bentuk aslinya. Meski pernah mengalami dua kali pemindahan, bangunan inti masjid ini tetap asli. Bangunan ini mengalami renovasi kedua kali pada tahun 1895 dengan penambahan serambi di depan atau bagian timur masjid.

Masjid berkali-kali mengalami renovasi sekunder setelah masa kemerdekaan Indonesia. Pada tahun 1959, lantai masjid mulai menggunakan semen yang sebelumnya masih berkerikil. Setelah itu terjadi dua kali renovasi besar-besaran, yaitu pada Desember 1990-Januari 1991 dengan pergantian 12 buah tiang sebagai kolom penunjang dan balok penopang atap. Pada tahun 1993 dilakukan pergantian balok penadah kasau dan bubungan, dengan tidak mengganti empat buah tiang sebagai kolom utama. Pada tahun 1997, atap masjid yang semula menggunakan seng diganti dengan bahan (semula) dari nipah. Atap nipah diganti setiap lima tahun sekali. Meski pernah direnovasi berkali-kali, masjid ini tetap asli karena tidak mengubah bentuk inti masjid sama sekali. Sehingga, dapat dikatakan bahwa masjid ini sebagai masjid tertua di tanah air yang masih terpelihara keasliannya hingga kini Maret 2008 lalu, Masjid ini direnovasi kembali. Struktur atap yang terbuat dari pelepah sagu diganti yang baru.

\section{PENUTUP}

\section{Kesimpulan}

Dari pembahasan terdahulu, dapat ditarik kesimpulan sebagai berikut:

Masjid Wapauwe diyakini merupakan mesjid tertua di Maluku bahkan di Indonesia. Masjid ini dibangun oleh Tuni Ulama pada tahun 1414. Struktur konstruksi bangunan Masjid Wapauwe bergaya tradisional sesuai dengan kemajuan teknologi pada zamannya dengan memanfaatkan unsur material lokal. Empat tiang utama terbuat dari Kayu Nani (Bintanggur atau Callophylum Soulattri) merupakan lambang dari 4 orang sahabat utama Rasulullah SAW. Dan 12 tiang pembantu serta rangka atap terbuat dari kayu merah melambangkan tanggal kelahiran Nabi Muhammad SAW. Tiang alif yang terletak sebagai kemuncak masjid ini bermakna Tuhan Yang Maha Esa (satu) yakni Allah SWT. Dinding bagian bawah menggunakan Lupuh yang merupakan sejenis batu karang yang dibakar yang berfungsi sebagai perekat/ semen, sedang dinding bagian atas menggunakan gaba-gaba/pelepah daun sagu. Konstruksi bangunan induknya dirancang tanpa memakai paku atau pasak kayu pada setiap sambungan, baik antara tiang dengan balok maupun antara balok dengan balok dan hanya diperkuat dengan ikatan yang dapat menjamin kokohnya bangunan. Atap masjid terbuat dari daun rumbia bergaya tradisional khas Maluku menggunakan model piramida. Keberadaan masjid ini mencerminkan tingginya peradaban Islam Tanah Hitu pada masa lalu.

\section{Rekomendasi}

Berdasarkan kesimpulan tersebut di atas, penelitian ini merekomendasikan:

1. Pentingnya dilaksanakan penelitian dan pengkaj ian yang lebih komprehensif di bidang arkeologi dan arsitektur sehingga dapat membantu pengungkapan arti dan makna dibalik simbol serta gaya peninggalan arkeologi Islam di Maluku hingga dapat dijadikan referensi dalam penulisan sejarah Islam Maluku yang lebih faktual.

2. Perlu dilakukan usaha untuk melakukan pelestarian dengan memberikan perlindungan terhadap bangunan arkeologi keagamaan yang bernilai sejarah.

\section{Ucapan Terima Kasih}

Penulis mengucapkan terima kasih kepada Kepala Balai Litbang Kementerian Agama Makassar yang telah banyak membimbing penulis. Ketua Bidang Lektur dan Khazanah Keagamaan beserta Sekertaris dan seluruh peneliti di Balai Litbang Agama Makassar. Kepada Kepala Kanwil Kementerian Agama Prov. Maluku beserta jajaran yang telah banyak membantu penulis selama penelitian terkhusus kepada Kepala KUA Kec. Leihitu Drs Bakry Talaohu. Bpk. Djafar Lain dan Raja Keitetu yang telah memberikan berbagai data yang dibutuhkan. Terima kasih yang tak terhingga buat redaktur Jurnal Al-Qalam yang telah bersedia menerbitkan tulisan ini, Special thanks to all editor tulisan ini. 


\section{DAFTAR PUSTAKA}

Abdul Baqir Zein. 1999. Mesjid-Mesjid Bersejarah di Indonesia. Jakarta: Gema Insani Press.

Ambary, Hasan Muarif. 2001. Menemukan Peradaban Jejak Arkeologis dan Historis Islam Indonesia. Jakarta: Logos Wacana Ilmu.

Badan Penelitian dan Pengembangan Agama Departemen Agama RI. 1999, Sejarah Mesjid-Mesjid Kuno di Indonesia. Jakarta: Badan Litbang Agama.

Balai Penelitian Lektur Keagamaan Ujung Pandang, Badan Penelitian dan Pengembangan Agama Departemen Agama RI, 1984. Benda-benda Bersejarah Bercirikan Keagamaan di Sulawesi Selatan. Ujung Pandang: Badan Litbang Agama.

HadiW.M., Abdul, (ed). 2008. Dari Hitu ke Barus. Jakarta. Pusat Bahasa Departemen Pendidikan Nasional

Haris, Tawalinuddin, 2009. Mesjid-Mesjid di Dunia MelayuNusantara, Diklat Penelitian Arkeologi I Ciputat Agustus, 2009. Jakarta: Puslektur Keagamaan Badan Litbang dan Diklat Departemen Agama.

Joseph, LC. Dan Rijoli, Frans. 2005. Arsitektur Tradisional Maluku. Dalam Maluku Menyambut Masa Depan (Hal. 49-65). Ambon. Lembaga Kebudayaan Daerah Maluku.

Kementerian Agama Badan Litbang dan Diklat Tahun 2010, Rencana Strategi Badan Litbang dan Diklat Kementerian Agama. Jakarta: Badan Litbang dan Diklat.

Pattikayhatu. 1987. Inventarisasi dan Dokumentasi Peninggalan Sejarah danPurbakala diKecamatan LeihituPulau Ambon. Ambon. Laporan Hasil Penelitian. Fakultas Keguruan dan Ilmu Pendidikan Universitas Pattimura.

Pijper, G.F., 1984. "Mesjid-Mesjid di Pulau Jawa", dalam: Tudjimah (Penerjemah). Penelitian TentangAgama Islam di Indonesia 1930-1950, Jakarta: Penerbit UI Press.

Puslitbang Arkenas. 2008. Metode Penelitian Arkeologi. Jakarta: Cetakan Kedua

Sumalyo, Yulianto. 2000. ArsitekturMesjiddanMonumen Sejarah Muslim. Yogyakarta: Gadjah Mada University Press.

Tjandrasasmita, Uka. 2000. Penelitian Arkeologi Islam di Indonesia Dari Masa ke Masa. Kudus: Menara Kudus.

Tjandrasasmita, Uka. 2009. Arkeologi Islam Nusantara. Jakarta: Kepustakaan Gramedia Populer (KPG).

\section{Informan:}

Dja'far Sain, wawancara Ambon, 27 Mei 2011 pukul 13.40 